\title{
KEWENANGAN PEMERINTAH DALAM PERLINDUNGAN HUKUM PELAYANAN KESEHATAN TRADISIONAL DITINJAU DARI UNDANG-UNDANG REPUBLIK INDONESIA NOMOR 36 TAHUN 2009 TENTANG KESEHATAN
}

\author{
Bunga Agustina \\ Fakultas Hukum Universitas Katolik Parahyangan \\ E-mail: bungaagustina1985@yahoo.com
}

\begin{abstract}
Health is a human right and one of the elements of the welfare state that must be realized in accordance with the ideals of the nation of Indonesia as stipulated in the Pancasila and the Preamble of the Constitution of the Republic of Indonesia Year 1945. Government as the highest authority has the authority to realize the health status of the highest for public health efforts by organizing a comprehensive integrated approach to promote, to preventive, to curative and to rehabilitative.

The results showed that the Indonesian positive law, namely Law of The Republic Indonesia Number 36 of 2009 on Health has not fully provide legal protection to businesses of traditional health services by traditional health workers as well as for consumers of traditional health care which patients/clients traditional health services. Therefore, the government should establish specific legislation governing traditional health services in particular because of traditional health services increasingly diverse treatment techniques and more trusted by Indonesian society.
\end{abstract}

Keywords: government authority; legal protection; traditional health services.

\section{Abstrak}

Kesehatan adalah hak asasi manusia dan salah satu unsur kesejahteraan yang harus diwujudkan negara sesuai dengan cita-cita bangsa Indonesia sebagaimana dimaksud dalam Pancasila dan Pembukaan UUD Negara Republik Indonesia Tahun 1945. Pemerintah sebagai pemegang kekuasaan tertinggi memiliki kewenangan untuk mewujudkan derajat kesehatan yang setinggi-tingginya bagi masyarakat dengan melakukan upaya kesehatan yang terpadu menyeluruh dengan pendekatan promotif, preventif, kuratif dan rehabilitatif.

Hasil penelitian menunjukkan bahwa Undang-Undang Nomor 36 Tahun 2009 tentang Kesehatan belum sepenuhnya memberikan perlindungan hukum kepada pelaku usaha pelayanan kesehatan tradisional yaitu penyehat tradisional atau tenaga kesehatan tradisional maupun untuk konsumen pelayanan kesehatan tradisional yaitu pasien/klien pelayanan kesehatan tradisional. Oleh karenanya, pemerintah hendaknya membentuk perundangan-undangan khusus yang mengatur pelayanan kesehatan tradisional secara khusus dikarenakan pelayanan kesehatan tradisional semakin beragam teknik pengobatannya dan semakin dipercaya manfaatnya oleh masyarakat Indonesia.

Kata Kunci: Kewenangan Pemerintah, Perlindungan Hukum, Pelayanan Kesehatan Tradisional. 


\section{A. PENDAHULUAN}

Dalam pembukaan Undang-Undang Dasar 1945 tercantum jelas citacita bangsa Indonesia yang sekaligus merupakan tujuan nasional bangsa Indonesia. Tujuan nasional tersebut adalah melindungi segenap bangsa Indonesia dan seluruh tumpah darah Indonesia, memajukan kesejahteraan umum, mencerdaskan kehidupan bangsa dan ikut melaksanakan ketertiban dunia yang berdasarkan kemerdekaan perdamaian abadi serta keadilan sosial. Untuk mencapai tujuan nasional tersebut diselenggarakanlah upaya pembangunan yang berkesinambungan yang merupakan suatu rangkaian pembangunan yang menyeluruh, terarah dan terpadu, termasuk di antaranya pembangunan kesehatan.

Kesehatan merupakan hak asasi manusia dan salah satu unsur kesejahteraan yang harus diwujudkan negara sesuai dengan cita-cita bangsa Indonesia sebagaimana dimaksud dalam Pancasila dan Pembukaan Undang-Undang Dasar Negara Republik Indonesia Tahun 1945. Oleh karena itu, setiap kegiatan dan upaya untuk meningkatkan derajat kesehatan masyarakat yang setinggitingginya dilaksanakan berdasarkan prinsip nondiskriminatif, partisipatif, perlindungan, dan berkelanjutan yang sangat penting artinya bagi pembentukan sumber daya manusia Indonesia, peningkatan ketahanan dan daya saing bangsa, serta pembangunan nasional.

Pembangunan nasional harus dilandasi dengan wawasan kesehatan yang artinya pembangunan nasional itu sendiri harus memperhatikan kesehatan masyarakat. Apabila terjadi suatu hal yang menyebabkan gangguan kesehatan pada masyarakat Indonesia tentunya akan menimbulkan kerugian ekonomi yang besar bagi negara, tapi di sisi lain setiap keberhasilan upaya peningkatan derajat kesehatan masyarakat akan meningkatkan investasi bagi pembangunan negara. Oleh karena itu, semua pihak baik pemerintah maupun masyarakat bertanggung jawab dalam memperhatikan kesehatan masyarakat.

Sebagai pemegang kekuasaan tertinggi, Negara bertanggung jawab dalam mengatur setiap upaya peningkatan derajat kesehatan masyarakat. Atas dasar itulah maka Negara membentuk UndangUndang Republik Indonesia Nomor 36 Tahun 2009 tentang Kesehatan untuk mengatur mengenai bidang kesehatan di Indonesia. Untuk selanjutnya, UndangUndang Republik Indonesia Nomor 36 Tahun 2009 tentang Kesehatan akan disebut dengan UU Kesehatan.

Kesehatan memiliki makna dan dimensi yang luas sesuai definisi menurut WHO maupun UU Kesehatan, yaitu keadaan sehat yang meliputi aspek fisik, mental, spiritual dan sosial serta dapat produktif secara sosial maupun ekonomis. ${ }^{1}$ Hal ini menunjukkan bahwa status kesehatan seseorang tidak hanya diukur dari aspek fisik dan mental semata, namun juga dinilai berdasarkan produktivitas sosial atau ekonomi. Kesehatan mental (jiwa) mencakup komponen pikiran, emosional dan spiritual. Secara spiritual, 
sehat tercermin dari praktek keagamaan, kepercayaan, dan perbuatan yang baik sesuai norma dalam masyarakat. ${ }^{2}$ Dalam upaya peningkatan derajat kesehatan masyarakat diperlukan suatu Upaya Kesehatan.

"Upaya kesehatan adalah setiap kegiatan dan/atau serangkaian kegiatan yang dilakukan secara terpadu, terintegrasi dan berkesinambungan untuk memelihara dan meningkatkan derajat kesehatan masyarakat dalam bentuk pencegahan penyakit, peningkatan kesehatan, pengobatan penyakit, dan pemulihan kesehatan oleh pemerintah dan/atau masyarakat". $^{3}$

Dalam mewujudkan derajat kesehatan yang setinggi-tingginya bagi masyarakat diselenggarakan upaya kesehatan yang terpadu dan menyeluruh dalam bentuk upaya kesehatan perorangan dan upaya kesehatan masyarakat. Upaya kesehatan diselenggarakan dalam bentuk kegiatan dengan pendekatan promotif, preventif, kuratif, dan rehabilitatif yang dilaksanakan secara terpadu, menyeluruh.

Penyelenggaraan upaya kesehatan dilaksanakan melalui kegiatan:

1. pelayanan kesehatan;

2. pelayanan kesehatan tradisional;

3. peningkatan kesehatan dan pencegahan penyakit;

4. penyembuhan penyakit dan pemulihan kesehatan;
5. kesehatan reproduksi;

6. keluarga berencana;

7. kesehatan sekolah;

8. kesehatan olahraga;

9. pelayanan kesehatan pada bencana;

10. pelayanan darah;

11. kesehatan gigi dan mulut;

12. penanggulangan gangguan penglihatan dan gangguan pendengaran;

13. kesehatan matra;

14. pengamanan dan penggunaan sediaan farmasi dan alat kesehatan;

15. pengamanan makanan dan minuman;

16. pengamanan zat adiktif; dan/atau

17. bedah mayat. ${ }^{4}$

Di dalam masyarakat Indonesia, dikenal 2 (dua) teknik pengobatan yaitu pengobatan konvensional dan pengobatan tradisional. Pengobatan konvensional merupakan suatu teknik pengobatan modern yang dilakukan oleh seorang dokter. Sedangkan pengobatan tradisional adalah pengobatan dan/atau perawatan dengan cara, obat dan pengobatnya yang mengacu kepada pengalaman, keterampilan turun temurun, dan atau pendidikan/pelatihan, dan diterapkan sesuai dengan norma yang berlaku dalam masyarakat. ${ }^{5}$ Teknik-teknik pengobatan itu dapat dikelompokan menjadi dua jenis pelayanan kesehatan yaitu:

1. Pelayanan kesehatan konvensional atau pelayanan kesehatan modern adalah pengobatan yang dilakukan oleh seorang dokter dengan caracara modern/ilmiah atau telah diuji

\footnotetext{
Soekidjo Notoatmodjo, Pendidikan dan Perilaku Kesehatan, PT. Rineka Cipta, Jakarta, 2003, hlm. 3-4.

Pasal 1 Angka 11 UU Kesehatan.

Pasal 41 Ayat (1) UU Kesehatan.

Pasal 1 Angka 1 Keputusan Menteri Kesehatan RI No 1076/Menkes/SK/VII/2003 Tentang

Penyelenggaraan Pengobatan Tradisional.
} 
cobakan dengan sebuah penelitian dan dapat dipertanggungjawabkan.

2. Pelayanan kesehatan tradisional adalah pengobatan dan/atau perawatan dengan cara dan obat yang mengacu pada pengalaman dan keterampilan turun temurun secara empiris yang dapat dipertanggungjawabkan dan diterapkan sesuai dengan norma yang berlaku di masyarakat. $^{6}$

Pelayanan kesehatan tradisional sudah dikenal terlebih dahulu daripada pelayanan kesehatan konvensional. Keberadaan pelayanan kesehatan konvensional muncul setelah pelayanan kesehatan tradisional pada abad ke-19. Hanya saja karena metode yang digunakan lebih ilmiah dan teruji membuat pelayanan kesehatan konvensional lebih dipercaya oleh masyarakat. Tetapi ternyata dalam perkembangannya, pelayanan kesehatan tradisional yang umumnya banyak terdapat di masyarakat pedesaan mulai menarik kembali kepercayaan masyarakat perkotaan terhadap pelayanan kesehatan tradisional. Malpraktik pelayanan kesehatan konvensional membuat masyarakat membuka diri kembali pada pelayanan kesehatan tradisional yang menawarkan konsep back to the nature bahkan kemungkinan sembuh dari penyakit yang belum ditemukan obatnya di dunia medis.

Keputusan Menteri Kesehatan Republik Indonesia Nomor 1076/ MENKES/SK/VII/2003 menyebutkan bahwa klasifikasi pengobatan tradisional memiliki teknik pengobatan yang beragam seperti teknik pengobatan keterampilan, teknik pengobatan ramuan, teknik pengobatan melalui pendekatan agama maupun teknik pengobatan melalui pendekatan supranatural. Sedangkan dalam Peraturan Pemerintah No. 103 Tahun 2014 tentang Pelayanan Kesehatan Tradisional, Jenis-Jenis Pelayanan Kesehatan Tradisional meliputi: ${ }^{7}$

1. Pelayanan Kesehatan Tradisional Empiris

Pelayanan Kesehatan Tradisional Empiris adalah penerapan kesehatan tradisional yang manfaat dan keamanannya terbukti secara empiris.

2. Pelayanan Kesehatan Tradisional Komplementer

Pelayanan Kesehatan Tradisional Komplementer adalah penerapan kesehatan tradisional yang memanfaatkan ilmu biomedis dan biokultural dalam penjelasannya serta manfaat dan keamanannya terbukti secara ilmiah.

3. Pelayanan Kesehatan Tradisional Integrasi

Pelayanan Kesehatan Tradisional Integrasi adalah suatu bentuk pelayanan kesehatan yang mengkombinasikan pelayanan kesehatan konvensional dengan Pelayanan Kesehatan Tradisional Komplementer, baik bersifat sebagai pelengkap atau pengganti.

Berdasarkan cara pengobatannya, Pelayanan Kesehatan Tradisional Empiris 
dan Pelayanan Kesehatan Tradisional Komplementer terbagi menjadi: ${ }^{8}$

1. Pelayanan yang menggunakan keterampilan; dan

2. pelayanan yang menggunakan ramuan.

Petugas kesehatan yang melakukan pelayanan kesehatan tradisional memiliki syarat-syarat dan kompetensi yang berbeda dalam melakukan pelayanan kepada publik. Untuk pelayanan kesehatan empiris, tenaga kesehatannya disebut penyehat tradisional. Syarat untuk menjadi seorang penyehat tradisional harus memiliki keterampilan dan memiliki Surat Terdaftar Penyehat Tradisional (STPT) yang dikeluarkan oleh Dinas Kesehatan setempat. Untuk pelayanan kesehatan komplementer, tenaga kesehatannya disebut tenaga kesehatan tradisional. Syarat untuk menjadi seorang tenaga kesehatan tradisional prosesnya tidak semudah penyehat tradisional. Para tenaga kesehatan tradisional harus memiliki keterampilan dari sekolah tinggi tertentu, setara minimal pendidikan D3 dan juga harus memiliki Surat Tanda Registrasi Tenaga Kesehatan Tradisional (STRTKT) dan Surat Izin Praktek Tenaga Kesehatan Tradisional(SIPTKT)yangdikeluarkanoleh pemerintah daerah. Pemerintah memiliki kewenangan penuh dalam mengatur dan menegakkan peraturan dalam mengawasi peredaran obat tradisional. Pemerintah perlu bertindak tegas dalam mengatur peredaran obat tradisional yang beredar dalam masyarakat. Banyak beredar obat tradisional yang tidak terdaftar bahkan mengandung bahan kimia yang dapat membahayakan masyarakat. Belum lagi pelayanan kesehatan tradisional melalui pendekatan agama dan pendekatan supranatural yang dirasakan belum ada pengaturan yang jelas dari pemerintah.

Sebelumnya dikatakan, bahwa pelayanan kesehatan tradisional merupakan teknik pengobatan dengan cara dan obat yang mengacu pada pengalaman dan keterampilan turun temurun secara empiris yang dapat dipertanggungjawabkan dan diterapkan sesuai dengan norma yang berlaku di masyarakat, pengalaman dan keterampilan turun temurun yang dapat dipertanggungjawabkan dan diterapkan merupakan unsur yang penting dalam menyelenggarakan suatu pelayanan kesehatan tradisional. Pengalaman dan keterampilan pelayanan kesehatan tradisional harus dapat dibuktikan sebagai sesuatu yang berdaya guna bagi masyarakat, aman untuk dilakukan dan tentunya dapat meningkatkan derajat kesehatan setinggi-setingginya. Dalam masyarakat, pelayanan kesehatan tradisional ini semakin berkembang dan beragam bentuk dalam masyarakat. Pemerintah perlu mengatur secara tegas mengenai pelayanan kesehatan tradisional ini agar tidak keluar dari jalur tujuan kesehatan itu sendiri yaitu meningkatkan derajat kesehatan yang setinggi-tinginya. Perlu adanya perlindungan hukum terhadap pelayanan kesehatan tradisional yang bertujuan untuk melindungi para tenaga kesehatan tradisional maupun pengguna pelayanan kesehatan tradisional itu sendiri.

8 Penjelasan Peraturan Pemerintah Nomor 103 Tahun 2014 Tentang Pelayanan Kesehatan Tradisional. 
Negara sebagai pemegang kekuasaan tertinggi seharusnya dapat menjamin penyelenggaraan kesehatan dalam bentuk pelayanan kesehatan tradisional agar dapat berjalan sebagaimana mestinya karena hakekat pemerintahan sendiri adalah pelayanan kepada masyarakat. Pemerintahan ada karena kehendak rakyat, untuk itu pemerintahan diadakan bukan untuk melayani dirinya sendiri, tetapi untuk melayani masyarakat serta menciptakan kondisi yang menginginkan setiap masyarakat mengembangkan kemampuan dan kreativitasnya demi mencapai tujuan bersama. ${ }^{9}$ Penentuan pengaturan bidang-bidang tersebut didasari oleh kewenangan atau wewenang pemerintah baik itu pemerintah pusat maupun daerah. Kewenangan menjadi kunci penentuan terlaksananya urusan pemerintahan tersebut.

Undang-Undang Republik Indonesia Nomor 23 Tahun 2014 tentang Pemerintahan Daerah yang selanjutkan akan disebut UU Pemerintahan Daerah menyebutkan bahwa kewenangan pemerintah dapat direfleksikan melalui pembagian urusan pemerintahan yang dibagi menjadi tiga kategori, yaitu: urusan pemerintahan absolut, urusan pemerintahan konkuren, dan urusan pemerintahan umum. ${ }^{10}$ Kategorisasi urusan pemerintahan ini muncul untuk menunjukkan prioritas pengaturan dan pengurusan yang dilakukan oleh pemerintah pusat, dan pemerintah daerah. Urusan pemerintahan absolut berada pada wewenang Pemerintah Pusat dan dapat dilimpahkan kepada pemerintahan daerah dengan berdasarkan asas dekonsentrasi. ${ }^{11}$ Urusan Pemerintahan Konkuren menjadi kewenangan Daerah terdiri atas Urusan Pemerintahan Wajib dan Urusan Pemerintahan Pilihan. ${ }^{12}$ Urusan Pemerintahan Umum merupakan urusan pemerintahan yang menjadi kewenangan presiden sebagai kepala pemerintahan. ${ }^{13}$

Salah satu kaitan kewenangan dengan pengkategorian urusan pemerintahan mengenai kesehatan terdapat dalam bagian urusan pemerintahan konkuren yang mengatur tentang Urusan Pemerintahan Wajib yang berkaitan dengan Pelayanan Dasar dan Urusan Pemerintahan yang tidak berkaitan dengan Pelayanan Dasar. ${ }^{14}$ Pasal 12 (1) UU Pemerintahan Daerah membagi Urusan Pemerintahan Wajib yang berkaitan dengan Pelayanan Dasar meliputi:

1. pendidikan;

2. kesehatan;

3. pekerjaan umum dan penataan ruang;

4. perumahan rakyat dan kawasan permukiman;

5. ketenteraman, ketertiban umum, dan pelindungan masyarakat; dan

6. sosial.

Pemerintah sebagai pemegang kekuasaan tertinggi dan pemilik kewenangan untuk mengatur bidang

\footnotetext{
9 Ryas Rasyid, Desentralisasi Dalam Menunjang Pembangunan Daerah Dalam Pembangunan Administrasi Di Indonesia, LP3ES, Jakarta, tanpa tahun, hlm. 13.

10 Pasal 9 UU Pemerintahan Daerah.

11 Lihat Pasal 10 ayat (1) dan (2) UU Pemerintahan Daerah.

12 Lihat Pasal 11 ayat (1) UU Pemerintahan Daerah.

13 Pasal 9 ayat (5) UU Pemerintahan Daerah.

14 Pasal 11 ayat (2) UU Pemerintahan Daerah.
} 
kesehatan memiliki tanggung jawab untuk memenuhi hak atas kesehatan yang merupakan salah satu hak asasi manusia dan salah satu unsur kesejahteraan yang harus diwujudkan untuk mencapai cita-cita bangsa Indonesia. Indonesia sebagai negara yang menganut konsep negara kesejahteraan, sebagaimana diungkapkan Jimly Asshiddiqie yang dikutip oleh W. Riawan Tjandra dituntut untuk memperluas tanggung jawabnya kepada masalah-masalah yang dihadapi oleh rakyat banyak. Fungsi negara pun diperluas meliputi pelayanan sosial kepada individu dan keluarga dalam hal-hal khusus, seperti 'social security', kesehatan, kesejahteraan sosial, pendidikan dan pelatihan serta perumahan. ${ }^{15}$ Tingkat kesehatan masyarakat akan sangat berpengaruh terhadap tingkat kesejahteraan masyarakat dan memiliki keterkaitan yang erat dengan kemiskinan. Tingkat kemiskinan pun akan terkait dengan tingkat kesejahteraan. Kesehatan merupakan faktor utama dalam upaya peningkatan kesejahteraan masyarakat, maka kesehatan selalu menjadi perhatian utama pemerintah sebagai penyelenggara pelayanan publik. Pemerintah harus dapat menjamin hak masyarakat untuk sehat dengan memberikan pelayanan kesehatan secara adil, merata, memadai, terjangkau, dan berkualitas. ${ }^{16}$ Karena tanpa memenuhi hak atas kesehatan, maka welfare state tidak akan terwujud. ${ }^{17}$
Oleh karena itu, sebagai pengemban amanat untuk menyejahterakan masyarakat maka negara berkewajiban untuk menghormati, melindungi dan memenuhi hak-hak asasi kesehatan tersebut. Kewajiban menghormati itu seperti menciptakan persamaan akses pelayanan kesehatan, pencegahan dari tindakan-tindakan yang dapat menurunkan status kesehatan masyarakat, melakukan langkah-langkah legislasi yang dapat menjamin perlindungan kesehatan masyarakat, membuat kebijakan kesehatan, penyediaan anggaran yang memadai, penyediaan jasa-jasa pelayanan kesehatan tradisional yang yang layak dan memadai untuk seluruh masyarakat.

Berdasarkan hal tersebut di atas, penulis akan membahas:

1. Bagaimana kewenangan pemerintah dalam perlindungan hukum pelayanan kesehatan tradisional menurut Undang-Undang Republik Indonesia Nomor 36 Tahun 2009 Tentang Kesehatan?

2. Bagaimana bentuk kewenangan pemerintah dalam perlindungan hukum yang ideal untuk pelayanan kesehatan tradisional menurut Undang-Undang Republik Indonesia Nomor 36 Tahun 2009 Tentang Kesehatan?

15 W. Riawan Tjandra, Hukum Administrasi Negara, Universitas Atma Jaya, Yogyakarta, 2008, hlm. 9.

16 Radhitya Widyasworo, Analisis Pengaruh Pendidikan, Kesehatan, Dan Angkatan Kerja Wanita Terhadap Kemiskinan Di Kabupaten Gresik (Studi Kasus Tahun 2008 - 2012), Jurnal Ilmiah, Fakultas Ekonomi Dan Bisnis Universitas Brawijaya, Malang, 2014, hlm. 4.

17 Mailinda Eka Yuniza, Pengaturan Pelayanan Kesehatan Di Kota Yogyakarta Setelah Penerapan Otonomi Luas, Mimbar Hukum Volume 25, Nomor 3, Oktober 2013, hlm. 378. 


\section{B. PEMBAHASAN}

\section{Perlindungan Hukum Melalui Pengaturan Undang-Undang}

Republik Indonesia Nomor 36 Tahun 2009 Tentang Kesehatan Terhadap Pelayanan Kesehatan Tradisional

Setiap penyelenggaraan kenegaraan dan pemerintahan memiliki legitimasi, yaitu kewenangan yang diberikan oleh undang-undang. Sehingga secara normatif menyebabkan setiap tindakan pemerintah harus berdasarkan peraturan perundangundangan atau berdasarkan pada kewenangan. Wewenang pemerintahan ini sekaligus menjadi fungsi kontrol rakyat terhadap pemerintah dalam bertindak. Wewenang pemerintah bersifat atribusi yang berasal dari peraturan perundangundangan. Dengan kata lain, organ pemerintah memperoleh kewenangan secara langsung dari redaksi pasal tertentu dalam suatu peraturan perundangundangan. Setiap pemberian kewenangan kepada pejabat pemerintahan tertentu, tersirat di dalamnya pertanggungjawaban dari pejabat yang bersangkutan.

Ada beberapa cara perlindungan secara hukum, antara lain sebagai berikut: 1. Membuat peraturan (by giving regulation), yang bertujuan untuk:

a. Memberikan hak dan kewajiban;

b. Menjamin hak-hak para subyek hukum

2. Menegakkan peraturan (by the law enforcement) melalui:

a. Hukum Administrasi Negara yang berfungsi untuk mencegah (preventif) terjadinya pelanggaran

hak-hak konsumen, dengan perijinan dan pengawasan.

b. Hukum pidana yang berfungsi untuk menanggulangi (repressive) setiap pelanggaran terhadap peraturan perundang-undangan, dengan cara mengenakan sanksi hukum berupa sanksi pidana dan hukuman;

c. Hukum perdata yang berfungsi untuk memulihkan hak (curative, recovery), dengan membayar kompensasi atau ganti kerugian. ${ }^{18}$

Perlindungan hukum terhadap pelayanan kesehatan tradisional haruslah dapat mencakup kepentingan semua stakeholders yaitu tenaga kesehatan tradisional maupun pasien pelayanan kesehatan tradisional. Kewenangan pemerintah dalam melindungi stakeholders pelayanan kesehatan tradisional dapat ditinjau dari segi hukum kesehatan, hukum pemerintahan daerah, hukum perlindungan konsumen, dan juga hukum pidana. Dalam melindungi para stakeholders pelayanan kesehatan tradisional pemerintah berwenang dan berkewajiban untuk membuat dan menegakkan peraturan mengenai pelayanan kesehatan tradisional secara menyeluruh sehingga dapat melindungi seluruh stakeholders.

Pemerintah mengatur mengenai pelayanan kesehatan tradisional dalam Undang-Undang Republik Indonesia No. 36 Tahun 2009 tentang Kesehatan dan Peraturan Pemerintah No. 103 Tahun

18 Wahyu Sasongko, Ketentuan-Ketentuan Pokok Hukum Perlindungan Konsumen, Penerbit Universitas Lampung, Bandar Lampung, 2007, hlm. 31. 
2014 tentang Pelayanan Kesehatan Tradisional. Peraturan Pemerintah mengatur pelayanan kesehatan tradisional lebih rinci dan menyeluruh apabila dibandingkan dengan UU Kesehatan yang hanya mengatur dalam beberapa pasal yaitu Pasal 1 Angka 9, Pasal 1 Angka 16, Pasal 48, Pasal 48, Pasal 59, Pasal 60 dan Pasal 61.

Hasil penelitian menunjukkan bahwa UU Kesehatan telah mengalami deregulasi karena banyak ditemukan kekosongan hukum yang akhirnya diakomodasi oleh Peraturan Pemerintah No. 103 Tahun 2014 tentang Pelayanan Kesehatan Tradisional. Hal ini menunjukkan bahwa UU Kesehatan tidak memberikan perlindungan hukum yang penuh terhadap pelayanan kesehatan tradisional karena lebih banyak mengatur hal-hal yang bersifat prinsipil atau mendasar mengacu pada tujuan kegiatan upaya kesehatan yang diharapkan dapat meningkatkan derajat kesehatan setinggitingginya. Agar tercipta suatu kesesuaian hukum positif yang berlaku dalam masyarakat yang sesuai dengan hierarki peraturan perundang-undangan nasional perlu dibentuk suatu Undang-undang mengenai pelayanan kesehatan tradisional yang dapat memberikan kepastian hukum bagi setiap stakeholders pelayanan kesehatan masyarakat tradisional.

Pasal 1 Undang-Undang Dasar Negara Republik Indonesia Tahun 1945 menyatakan bahwa Negara Indonesia adalah negara kesatuan yang berbentuk republik. Hal ini menimbulkan konsekuensi logis sebagai Negara kesatuan adalah dibentuknya pemerintah Negara Indonesia sebagai pemerintah nasional yang memiliki tugas untuk membentuk suatu daerah sebagai bagian dari negara kesatuan Indonesia. Kemudian, Pasal 18 ayat (2) dan ayat (5) Undang-Undang Dasar Negara Republik Indonesia Tahun 1945 menyatakan bahwa Pemerintahan Daerah berwenang untuk mengatur dan mengurus sendiri Urusan Pemerintahan menurut Asas Otonomi dan Tugas Pembantuan dan diberikan otonomi yang seluas-luasnya.

Sebelumnya setiap urusan pemerintahan yang merupakan kewenangan Presiden dan dilaksanakan oleh pemerintah daerah diatur dalam PP No. 38 Tahun 2007 Tentang Pemerintah, Pemerintah Provinsi dan Pemerintah Kabupaten/Kota. Sekarang segala sesuatu yang berhubungan dengan urusan pemerintahan atau penyelenggaraan daerah diatur dalam UU No. 23 Tahun 2014 tentang Pemerintahan Daerah. UU No. 23 Tahun 2014 tentang Pemerintahan Daerah lebih memudahkan pengaturan pembagian urusan pemerintahan karena mengatur dan melengkapi peraturan mengenai penyelenggaraan pemerintahan daerah yang sebelumya diatur oleh UU No. 32 Tahun 2004 mengenai Pemerintahan Daerah.

$$
\text { Pasal } 9 \text { ayat (3) UU No. } 23
$$

Tahun 2014 tentang Pemerintahan Daerah menyebutkan bahwa Urusan Pemerintahan Konkuren merupakan urusan pemerintahan yang dibagi antara Pemerintah Pusat dan Daerah provinsi dan Daerah kabupaten/kota. Urusan pemerintahan konkuren yang diserahkan ke Daerah menjadi dasar pelaksanaan Otonomi Daerah. Bidang kesehatan merupakan Urusan Pemerintahan Konkuren Wajib yang berkaitan dengan 
pelayanan dasaryang menjadi kewenangan

Daerah. Dalam Lampiran Pembagian Urusan Pemerintahan Konkuren Antara Pemerintah Pusat dan Daerah Provinsi dan Daerah Kabupaten/Kota UU No. 23 Tahun 2014 tentang Pemerintahan Daerah di bidang Kesehatan disebutkan secara terperinci wewenang pemerintahan dalam mengatur bidang kesehatan masyarakat.

\section{Kewenangan Pemerintah Pusat:}

1. Bidang Upaya Kesehatan

a. Pengelolaan upaya kesehatan perorangan (UKP) rujukan nasional/lintas Daerah provinsi.

b. Pengelolaan upaya kesehatan masyarakat (UKM) nasional dan rujukan nasional/lintas Daerah provinsi.

c. Penyelenggaraan registrasi, akreditasi, dan standardisasi fasilitas pelayanan kesehatan publik dan swasta.

d. Penerbitan izin rumah sakit kelas A dan fasilitas pelayanan kesehatan penanaman modal asing (PMA) serta fasilitas pelayanan kesehatan tingkat nasional.

2. Bidang Sumber Daya Manusia (SDM) Kesehatan

a. Penetapan standardisasi dan registrasi tenaga kesehatan Indonesia, tenaga kesehatan warga negara asing (TK-WNA), serta penerbitan rekomendasi pengesahan rencana penggunaan tenaga kerja asing (RPTKA) dan izin mempekerjakan tenaga asing (IMTA). b. Penetapan penempatan dokter spesialis dan dokter gigi spesialis bagi Daerah yang tidak mampu dan tidak diminati.

c. Penetapan standar kompetensi teknis dan sertifikasi pelaksana Urusan Pemerintahan bidang kesehatan.

d. Penetapan standar pengembangan kapasitas SDM kesehatan.

e. Perencanaan dan pengembangan SDM kesehatan untuk UKM dan UKP Nasional

3. Bidang Sediaan Farmasi, Alat Kesehatan, dan Makanan Minuman

a. Penyediaan obat, vaksin, alat kesehatan, dan suplemen kesehatan program nasional.

b. Pengawasan ketersediaan pemerataan, dan keterjangkauan obat dan alat kesehatan.

c. Pembinaan dan pengawasan industri, sarana produksi dan sarana distribusi sediaan farmasi, obat tradisional, alat kesehatan dan perbekalan kesehatan rumah tangga (PKRT), bahan obat, bahan baku alam yang terkait dengan kesehatan.

d. Pengawasan pre-marketobat, obat tradisional, kosmetika, alat kesehatan, PKRT, dan makanan minuman.

e. Pengawasan post-market obat, obat tradisional, kosmetika, alat kesehatan, PKRT, dan makanan minuman.

4. Bidang Pemberdayaan Masyarakat Bidang Kesehatan

Pemberdayaan masyarakat bidang kesehatan melalui tokoh nasional dan 
internasional, kelompok masyarakat, organisasi swadaya masyarakat serta dunia usaha tingkat nasional dan internasional.

\section{Kewenangan Pemerintah Daerah Provinsi di Bidang Kesehatan:}

1. Bidang Upaya Kesehatan
a. Pengelolaan UKP rujukan tingkat Daerah provinsi/lintas Daerah kabupaten/kota.
b. Pengelolaan UKM Daerah provinsi dan rujukan tingkat Daerah provinsi/lintas Daerah kabupaten/kota.
c. Penerbitan izin rumah sakit kelas B dan fasilitas pelayanan kesehatan tingkat Daerah provinsi.

2. Bidang Sumber Daya Manusia (SDM) Kesehatan

Perencanaan dan pengembangan SDM kesehatan untuknUKM dan UKP Daerah provinsi

3. Bidang Sediaan Farmasi, Alat Kesehatan, dan Makanan Minuman

a. Penerbitan pengakuan pedagang besar farmasi (PBF) cabang dan cabang penyalur alat kesehatan (PAK).

b. Penerbitan izin usaha kecil obat tradisional (UKOT).

4. Bidang Pemberdayaan Masyarakat Bidang Kesehatan

Pemberdayaan masyarakat bidang kesehatan melalui tokoh provinsi, kelompok masyarakat, organisasi swadaya masyarakat dan dunia usaha tingkat provinsi.

\section{Kewenangan Pemerintah Daerah Kabupaten/Kota di Bidang Kesehatan:}

1. Bidang Upaya Kesehatan
a. Pengelolaan UKP kabupaten/kota dan rujukan tingkat Daerah kabupaten/kota.
b. Pengelolaan UKM Daerah kabupaten/kota dan rujukan tingkat Daerah kabupaten/kota.
c. Penerbitan izin rumah sakit kelas C dan D dan fasilitas pelayanan kesehatan tingkat Daerah kabupaten/kota

2. Bidang Sumber Daya Manusia (SDM) Kesehatan
a. Penerbitan izin praktik dan izin kerja tenaga kesehatan.
b. Perencanaan dan pengembangan SDM kesehatan untuk UKM dan UKP Daerah kabupaten/kota.

3. Bidang Sediaan Farmasi, Alat Kesehatan, dan Makanan Minuman
a. Penerbitan izin apotek, toko obat, toko alat kesehatan dan optikal.
b. Penerbitan izin usaha mikro obat tradisional (UMOT).
c. Penerbitan sertifikat produksi alat kesehatan kelas 1 (satu) tertentu dan PKRT kelas 1 (satu) tertentu perusahaan rumah tangga.
d. Penerbitan izin produksi makanan dan minuman pada industri rumah tangga.
e. Pengawasan post-market produk makanan dan minuman industri rumah tangga.

4. Bidang Pemberdayaan Masyarakat Bidang Kesehatan

Pemberdayaan masyarakat bidang kesehatan melalui tokoh kabupaten/ kota kelompok masyarakat, organisasi 
swadaya masyarakat dan dunia usaha tingkat kabupaten/kota.

Peraturan Pemerintah No. 103 Tahun 2014 tentang Pelayanan Kesehatan Tradisional menyebutkan bahwa pelayanan kesehatan tradisional meliputi pelayanan kesehatan tradisional keterampilan dan pelayanan kesehatan tradisional ramuan. Dari kedua jenis pelayanan kesehatan tradisional ini, pemerintah memiliki kewenangan untuk mengatur secara penuh dalam Bidang Sumber Daya Manusia Kesehatan dan Bidang Sediaan Farmasi, Alat Kesehatan, dan Makanan Minuman. Pemerintah Daerah Kabupaten/Kota memiliki wewenang luas dan nyata dalam mengatur pelayanan kesehatan tradisional. Pemerintah Daerah Kabupaten/Kota yang dalam hal ini memiliki kewenangan untuk mengatur langsung pelayanan kesehatan tradisional adalah Dinas Kesehatan dan Badan Pengawas Obat dan Makanan. Dinas Kesehatan berkewenangan mengatur Sumber Daya Manusia Tenaga Kesehatan Tradisional dalam hal penerbitan izin praktik dan izin kerja untuk para tenaga kesehatan tradisional yang berkompeten. Sedangkan BPOM bertugas mengatur, meregistrasi dan mengawasi peredaran obat tradisional yang marak beredar dalam masyarakat.

2. Idealitas Perlindungan Hukum Terhadap Pelayanan Kesehatan Menurut Undang-Undang Republik Indonesia Nomor 36 Tahun 2009 Tentang Kesehatan

Tujuan dibentuknya UU Kesehatan adalah untuk mewujudkan kesejahteraan umum yang dalam hal ini adalah kesehatan masayrakat. Dalam rangka meningkatkan derajat kesehatan masyarakat yang setinggi-tingginya maka dilakukan berbagi upaya kesehatan yang dapat meningkatkan derajat kesehatan itu sendiri. Dalam UU Kesehatan diatur 17 bentuk upaya kesehatan yang diharapkan dapat meningkatkan derajat kesehatan yang setinggi-tingginya. Cita-cita itu didukung pula oleh metode pendekatan pelayanan kesehatan yang bertujuan untuk mengubah paradigma masyarakat mengenai kesehatan. Pada awalnya, pelayanan kesehatan hanya mengejar sifat kuratif pengobatan yaitu mengobati atau menyembuhkan yang sakit. Maka dari itu untuk menciptakan pelayanan kesehatan tradisional yang ideal diperlukan empat metode kesehatan yang saling berkaitan satu sama lain yaitu pendekatan promotif, pendekatan preventif dan pendekatan kuratif dan pendekatan rehabilitatif.

Pendekatan promotif merupakan salah satu pendekatan kesehatan yang bersifat promosi dimana ketika dilakukan suatu pelayanan kesehatan tradisional, pasien yang merasa lebih sehat ketika menggunakan pelayanan kesehatan tradisional dapat mempromosikan manfaat pelayanan kesehatan tradisional itu kepada anggota masyarakat yang lain sehingga pengguna pelayanan kesehatan tradisional dapat meningkat. Pendekatan preventif mengatur ke arah pencegahan suatu penyakit. Pelayanan kesehatan tradisional ditujukan untuk mencegah sebelum terjadinya suatu penyakit. Pelayanan kesehatan tradisional empiris diselenggarakan dengan menggunakan kedua metode ini pendekatan promotif dan pendekatan preventif. 
Pelayanan kesehatan tradisional komplementer diselenggarakan dengan menggunakan semua pendekatan pelayanan kesehatan. Untuk menciptakan perlindungan hukum yang ideal terhadap pelayanan kesehatan tradisional maka diperlukan kerjasama dari setiap stakeholders yang terkait dengan pelayanan kesehatan tradisional. Seluruh masyarakat wajib memahami konsep kesederajatan yang terdapat dalam UU Kesehatan.

Dalam UU No. 23 Tahun 2014 tentang Pemerintahan Daerah disebutkan bahwa Urusan Pemerintahan adalah Urusan Pemerintahan adalah kekuasaan pemerintahan yang menjadi kewenangan Presiden yang pelaksanaannya dilakukan oleh kementerian negara dan penyelenggara Pemerintahan Daerah untuk melindungi, melayani, memberdayakan, dan menyejahterakan masyarakat. Dalam hal ini, pemerintah daerah memiliki kewenangan untuk mengatur pelayanan kesehatan tradisional sehingga fungsi pelayanan kesehatan tradisional dapat melindungi, melayani, memberdayakan dan menyejahterakan masyarakat.

Fungsi melindungi lebih dilakukan kearah membuat suatu undang-undang khusus yang mengatur mengenai pelayanan kesehatan tradisional. UU Kesehatan tidak mengakomodasi penuh kepentingan stakeholders pelayanan kesehatan tradisional. Oleh karena itu, pemerintah hendaknya membentuk suatu undang-undang khusus yang dapat melakukan pengaturan pelayanan kesehatan tradisional secara menyeluruh. UU Pelayanan Kesehatan Tradisional dapat menjadi suatu peraturan yang memberikan kepastian hukum dan perlindungan hukum bagi setiap stakeholders pelayanan kesehatan tradisional. Di dalamnya perlu dicantumkan berbagai peraturan yang tersebar dalam PP No. 103 Tahun 2014 dan berbagai keputusan menteri mengenai pelayanan kesehatan tradisional dan peredaran obat tradisional mengingat pelayanan kesehatan tradisional tidak dapat dipisahkan dengan penggunaan obat tradisional. Dengan adanya pembentukan Undang-undang pelayanan kesehatan tradisional yang mengatur dengan lengkap mengenai pelayanan kesehatan tradisional tentunya akan serta merta melindungi pelayanan kesehatan tradisional itu sendiri karena pengaturan oleh undangundang yang khusus akan memberikan kekuatan yang bersifat mengikat.

Dalam fungsi melayani, Pemerintah berwenang menetapkan standar-standar pelayanan kesehatan tradisional. Dimulai dari standar pendidikan dan kompetensi yang seharusnya dimiliki oleh penyehat tradisional maupun tenaga kesehatan tradisional. Selain itu standar lain yang perlu ditentukan oleh pemerintah adalah standar tempat pelayanan seperti bangunan dan ruangan yang memadai seperti yang diatur oleh PP No. 103 tentang Pelayanan Kesehatan Tradisional. Fungsi melayani dapat juga diterapkan dalam proses pemberian izin oleh pemerintah kepada penyehat tradisional maupun tenaga kesehatan tradisional, pemerintah perlu membuat suatu sistem perizinan yang lebih efektif dan efisien sehingga dapat mengembangkan pelayanan kesehatan tradisional menjadi suatu bentuk usaha kesehatan. 
Fungsi memberdayakan lebih ditujukan kepada fungsi pemerintah untuk mengembangkan pelayanan kesehatan itu sendiri. Pemerintah harus dapat mengatur bahkan mengakomodasi agar terjadi peningkatan kederajatan suatu pelayanan kesehatan tradisional. Misalnya dalam pelayanan kesehatan empiris, pemerintah perlu mempertimbangkan untuk membuat sekolah atau tempat pendidikan untuk meningkatkan derajat pelayanan kesehatan empiris. Memberdayakan juga mengarahkan masyarakat untuk lebih mempercayaidan menggunakan pelayanan kesehatan tradisional, semakin banyak masyarakat yang menggunakan pelayanan kesehatan tradisional akan menyebabkan derajat kesehatan masyarakat semakin meningkat.

Fungsi yang terakhir adalah fungsi menyejahterakan, fungsi ini berisi kewenangan pemerintah untuk mengatur kesejahteraan pelayanan kesehatan tradisional maupun pasien atau klien pelayanan kesehatan tradisional. Pemerintah memiliki kewenangan untuk mengatur ukuran imbalan jasa bagi pelayanan kesehatan tradisional agar tidak terlalu murah bahkan tidak terlalu mahal seperti kebanyakan pelayanan kesehatan konvensional. Pemerintah memiliki kewenangan untuk mengatur agar pelayanan kesehatan tradisional dapat menjadi suatu pelayanan kesehatan yang bermutu bagi masyarakat dan dapat membantu masyarakat mendapatkan pelayanan kesehatan yang terbaik. Masyarakat yang sehat akan memberikan sumber daya manusia yang sehat dan berkualitas bagi pembangunan nasional.

\section{PENUTUP}

\section{Kesimpulan}

a. Kewenangan pemerintah dalam perlindungan hukum pelayanan kesehatan tradisional dapat dikaji dari fungsi pemerintahan berdasarkan perlindungan secara hukum. Ada tiga macam bentuk perlindungan hukum pemerintah yaitu sebagai pembuat undang-undang, pelaksana undangundang dan sebagai pengawas undangundang. Sebagai pembuat undangundang, pemerintah berwenang membuat suatu peraturan yang mengatur dengan konkrit mengenai pelayanan kesehatan tradisional. UU Kesehatan mengatur bidang kesehatan secara menyeluruh tapi tidak spesifik dalam mengatur pelayanan kesehatan tradisional. Pengaturan yang lebih khusus diatur dalam PP No. 103 tahun 2014 tentang Pelayanan Kesehatan Tradisional sebagai peraturan pelaksana UU Kesehatan. dalam PP No. 103 tahun 2014 tentang Pelayanan Kesehatan Tradisional disebutkan dengan jelas pengaturan mengenai pelayanan kesehatan tradisional dimulai dari pengertian, syarat-syarat, hak dan kewajiban pasien, hak dan kewajiban penyehat tradisional, hak dan kewajiban tenaga kesehatan tradsional, pendaftaran, perizinan, syarat suatu tempat pelayanan kesehatan dan sanksi-sanksi. PP No. 103 tahun 2014 tentang Pelayanan Kesehatan Tradisional mengatur pelayanan kesehatan tradisional dengan lebih jelas sehingga dapat dikatakan PP No. 103 tahun 2014 tentang Pelayanan Kesehatan 
Tradisional lebih memberikan perlindungan hukum bagi pelayanan kesehatan tradisional.

Sedangkan kewenangan pemerintah dalam hal pelaksanaan lebih diarahkan kepada pelaksanaan pelayanan kesehatan tradisional itu sendiri. Misalnya dalam pemberian izin praktik pelayanan kesehatan tradisional kepada tenaga kesehatan tradisional. Sistem pendaftaran yang dilakukan oleh penyehat tradisional belum menjamin suatu kepastian hukum dan tidak melindungi masyarakat pengguna pelayanan kesehatan tradisional. Hal ini dikarenakan dalam sistem pendaftaran, pemerintah hanya mengakui adanya pelayanan kesehatan tradisional tersebut sedangkan dalam sistem perizinan, ada unsur pengakuan pemerintah dan pemberian kewenangan oleh pemerintah kepada tenaga kesehatan tradisional. Sistem perizinan juga lebih bersifat melindungi secara hukum bagi tenaga kesehatan tradisional dalam melakukan pelayanan kesehatan tradisional bahwa tenaga kesehatan tradisional tidak diragukan kemampuannya karena mempunyai izin praktik. Masyarakat juga tentunya akan merasa aman dan nyaman dengan tenaga kesehatan tradisional yang jelas memiliki izin praktik.

Kewenangan pemerintah sebagai penegak undang-undang lebih dilakukan dalam memberikan sanksi apabila terjadi pelanggaran hukum. Ada dua jenis sanksi yaitu sanksi pidana dan sanksi administratif. Sanksi pidana akan diberikan apabila penyehat tradisional maupun tenaga kesehatan tradisional melakukan kelalaian sehingga menyebabkan pasien atau kliennya mengalami suatu kerugian atau bahkan kematian. Sedangkan sanksi administratif diberikan apabila penyehat tradisional maupun tenaga kesehatan tradisional tidak memenuhi standar pelayanan seperti standar pendidikan, standar kompetensi, standar operasional prosedur atau kode etik profesi.

b. Kewenangan pemerintah dalam mewujudkan perlindungan hukum yang ideal dalam pelayanan kesehatan tradisional dapat dilakukan melalui empat fungsi urusan pemerintah dalam menjalankan urusan pemerintahan yaitu melindungi, melayani, memberdayakan dan menyejahterakan masyarakat. Dengan menjalankan secara penuh keempat fungsi tersebut, pelayanan kesehatan tradisional akan mampu meningkatkan derajat kesehatan yang tinggi. Walapun mungkin tidak memiliki kualitas yang sama dengan pelayanan kesehatan konvensional tapi dengan memiliki prosedur dan standar pelayanan yang disesuaikan dengan pelayanan kesehatan konvensional diharapkan pelayanan kesehatan tradisional dapat meningkatkan kesejahteraan umum masyarakat Indonesia.

\section{Saran}

Berdasarkan uraian pada bab-bab sebelumnya dan kesimpulan di atas, dapat diuraikan beberapa saran sebagai berikut: 


\section{Saran untuk pemerintah:}

a. Seperti disebutkan sebelumnya bahwa UU Kesehatan tidak dapat mengakomodasi penuh kepentingan stakeholders pelayanan kesehatan tradisional. Oleh karena itu, pemerintah baik DPR maupun Presiden bersama-sama membentuk suatu undang-undang baru khusus tentang pelayanan kesehatan tradisional yang dapat melakukan pengaturan secara menyeluruh.

b. Pemerintah dalam hal ini Dinas Kesehatan hendaknya melakukan kerja sama dengan asosiasi pelayanan kesehatan tradisional atau organisasi professional untuk menetapkan suatu standar pelayanan yang dapat memberikan perlindungan hukum khususnya untuk pelayanan kesehatan tradisional empiris yang masih belum memiliki standar pelayanan minimal dikarenakan keterampilannya berasal dari pengalaman turun temurun.

c. Perlu mengkaji ulang sistem perizinan pelayanan kesehatan tradisional empiris karena sistem pendaftaran untuk melakukan pelayanan kesehatan tradisional tidak memberikan perlindungan hukum dan kepastian hukum bagi masyarakat.

d. Pemerintah perlu melakukan pembinaan terhadap pelayanan kesehatan empiris misalnya dengan menyediakan lapangan pendidikan untuk meningkatkan standar pendidikan dan standar kompetensi pelayanan kesehatan empiris.

e. Pemerintah perlu mempertimbangkan lebih lanjut mengenai status hukum pelayanan kesehatan tradisional chiropraksi dalam masyarakat mengingat pelayanan kesehatan tradisional ini hanya boleh dilakukan oleh dokter.

f. Pemerintah perlu mengambil tindakan tegas dalam menertibkan toko-toko obat tradisional yang tidak memiliki izin di masyarakat. Hal ini untuk mencegah peredaran obat tradisional yang membahayakan masyarakat.

\section{Saran untuk penyehat tradisional dan tenaga kesehatan tradisional:}

a. Penyehat tradisional maupun tenaga kesehatan tradisional harus selalu mengembangkan standar pendidikan dan standar kompetensinya untuk semakin meningkatkan derajat pelayanan kesehatan tradisional.

b. Penyehat tradisional maupun tenaga kesehatan tradisional harus memiliki SOP yang jelas dalam melayani pasien/ kliennya.

c. Penyehat tradisional maupun tenaga kesehatan tradisional harus selalu melayani pasien dengan prinsip kehatihatian agar tidak terjadi malpraktik

d. Penyehat tradisional maupun tenaga kesehatan tradisional harus menghormati setiap hak pasien dan memenuhi kewajibannya sebagai pemberi layanan.

\section{Saran untuk masyarakat:}

a. Masyarakat harus mencari informasi yang selengkapnya apabila akan memilih salah satu pelayanan kesehatan tradisional. Masyarakat harus menajadi pasien atau klien atau konsumen yang bijak dalam memilih pelayanan kesehatan tradisional terbaik bagi dirinya. 
b. Masyarakatjangan mudah terpengaruh oleh iklan-iklan pengobatan kesehatan tradisional yang berlebihan dan tidak wajar seperti jaminan kesembuhan $100 \%$ atau diskon yang tinggi untuk suatu pelayanan kesehatan tradisional.

c. Masyarakat harus waspada dan bijak terhadap peredaran obat tradisional. Ketika melakukan pemakaian obat tradisional, masyarakatharus waspada dan bijak dengan memperhatikan standar suatu obat tradisional seperti pencantuman no pendaftaran obat tradisional, label halal, komposisi obat dan standar obat lainnya.

\section{DAFTAR PUSTAKA}

Radhitya Widyasworo, Analisis Pengaruh Pendidikan, Kesehatan, Dan Angkatan Kerja Wanita Terhadap Kemiskinan Di Kabupaten Gresik (Studi Kasus Tahun 2008-2012), Jurnal Ilmiah, Fakultas Ekonomi Dan Bisnis Universitas Brawijaya, Malang, 2014.

Ridwan HR., Hukum Administrasi Negara, PT. Raja Grafindo Persada, Jakarta, 2014.

Ryas Rasyid, Desentralisasi Dalam Menunjang Pembangunan Daerah Dalam Pembangunan Administrasi Di Indonesia, LP3ES, Jakarta, tanpa tahun.

Satjipto Raharjo, Ilmu Hukum, PT. Citra Aditya Bakti, Bandung, 2000.

Soekidjo Notoatmodjo, Pendidikan dan Perilaku Kesehatan, PT. Rineka Cipta, Jakarta, 2003.
Soekidjo Notoatmodjo, Etika dan Hukum Kesehatan, Rineka Cipta, Jakarta 2010.

W. Riawan Tjandra, Hukum Administrasi Negara, Universitas Atma Jaya, Yogyakarta, 2008.

Wahyu Sasongko, Ketentuan-Ketentuan Pokok Hukum Perlindungan Konsumen, Penerbit Universitas Lampung, Bandar Lampung, 2007.

\section{Makalah, Hasil Penelitian dan Jurnal:}

Wahyu Sasongko, Makalah Relevansi dan Dinamika Perlindungan Hukum Bagi Konsumen, 1998

\section{Peraturan Perundang-Undangan:}

Undang-Undang Republik Indonesia Nomor 8 Tahun 1999 Tentang Perlindungan Konsumen.

Undang-Undang Republik Indonesia Nomor 36 Tahun 2009 tentang Kesehatan.

Undang-Undang Republik Indonesia Nomor 23 Tahun 2014 tentang Pemerintahan Daerah.

Peraturan Pemerintah Republik Indonesia Nomor 103 Tahun 2014 Tentang Pelayanan Kesehatan Tradisional.

Keputusan Menteri Kesehatan RI No 1076/Menkes/SK/VII/2003 Tentang Penyelenggaraan Pengobatan Tradisional. 